\title{
Phosphorus limitation and diel control of nitrogen-fixing cyanobacteria in the Baltic Sea
}

\author{
Pia H. Moisander ${ }^{1, *}$, Hans W. Paerl ${ }^{2}$, Julianne Dyble ${ }^{3}$, Kaarina Sivonen ${ }^{4}$ \\ ${ }^{1}$ Ocean Sciences Department, University of California Santa Cruz, 1156 High Street, Santa Cruz, California 95064, USA \\ ${ }^{2}$ Institute of Marine Sciences, University of North Carolina at Chapel Hill, 3431 Arendell Street, Morehead City, \\ North Carolina 28557, USA \\ ${ }^{3}$ National Oceanic and Atmospheric Administration, Great Lakes Environmental Research Laboratory, \\ 2205 Commonwealth Boulevard, Ann Arbor, Michigan 48105-2945, USA \\ ${ }^{4}$ University of Helsinki, Department of Applied Chemistry and Microbiology, PO Box 56, Biocenter Viikki, \\ 00014 Helsinki University, Finland
}

\begin{abstract}
Up to half of the annual new nitrogen inputs into the Baltic Sea originate from blooms of $\mathrm{N}_{2}$-fixing cyanobacteria. Estimates of the magnitude of this new nitrogen vary, partially because relatively few studies have investigated short-term changes in $\mathrm{N}_{2}$-fixation rates in response to environmental changes in situ, including phosphorus availability, one of the major factors limiting $\mathrm{N}_{2}$ fixation in the system. We examined cyanobacterial $\mathrm{N}_{2}$ fixation in response to phosphorus amendments over the diel cycle during 2002 and 2003 in the Baltic Sea, when both Nodularia spumigena and Aphanizomenon sp. formed blooms. Phosphorus stimulated $\mathrm{N}_{2}$ fixation in the open-sea areas in the Northern Baltic Proper and Gulf of Finland during both years. In microcosm experiments, both chlorophyll a concentration and $\mathrm{N}_{2}$ fixation were positively related to time $\left(\mathrm{R}^{2}=0.79\right.$ and 0.54 , respectively) for at least $4.5 \mathrm{~d}$ after the $\mathrm{P}$ amendment. $\mathrm{N}_{2}$ fixation was enhanced up to 3 -fold within $4.5 \mathrm{~d}$ by a single P pulse. $\mathrm{N}_{2}$ fixation continued in the dark at 16 to $61 \%$ of maximum rates during the day, and there were no consistent changes in nitrogenase enzyme abundance in response to darkness. Immunoblotting showed that $\mathrm{N}_{2}$ fixation is not regulated in response to darkness by size modifications of the Fe and MoFe proteins in N. spumigena or of the Fe protein of Aphanizomenon sp. Capability to fix $\mathrm{N}_{2}$ at high rates at night allows these cyanobacteria to maximize their utilization of periodic $\mathrm{P}$ pulses for subsequent growth.
\end{abstract}

KEY WORDS: Diel cycle · Nitrogenase regulation · Baltic Sea · Phosphorus limitation · Nodularia spumigena

Resale or republication not permitted without written consent of the publisher

\section{INTRODUCTION}

Only a few coastal embayments and estuaries, including the Baltic Sea, experience annual summertime $\mathrm{N}_{2}$-fixing cyanobacterial blooms (Niemi 1979, Paerl 1990). In places where these blooms occur, $\mathrm{N}_{2}$ fixation can be an ecologically significant process. Summertime $\mathrm{N}_{2}$-fixing cyanobacterial blooms provide as much as 10 to $55 \%$ of the annual $\mathrm{N}$ inputs into the Baltic Sea (Leppänen et al. 1988, Larsson et al. 2001, Wasmund et al. 2001). Three heterocystous cyanobacterial genera (Aphanizomenon sp., Nodularia spp., and Anabaena spp.) form the Baltic Sea cyano- bacterial blooms, with Nodularia spumigena and Aphanizomenon sp. dominating the cell abundances. Nodularia spumigena is the most visible of these cyanobacteria: its surface accumulations are extensive enough to be mapped by remote sensing (Kahru et al. 1994). In spite of numerous studies on Baltic Sea cyanobacterial blooms, taxa-specific differences in environmental and diurnal controls of their $\mathrm{N}_{2}$ fixation are not well understood (Lehtimäki et al. 1997, Evans et al. 2000).

Over large spatial and temporal scales (years to decades, hundreds of $\mathrm{km}$ ), phosphorus (P) availability and cyanobacterial bloom intensities in the Baltic Sea 
are closely linked with bottom-water redox conditions (Kiirikki et al. 2001). Over long periods of stagnation, oxygen in waters beneath the Baltic Sea halocline is consumed and anoxia develops (Nehring 1981). Under anoxic conditions, phosphate and ammonia are released, while in hypoxic waters and sediments, denitrification is promoted (Kuparinen \& Tuominen 2001). Both of these processes promote reductions in the N:P ratio in dissolved nutrients in the bottom waters. Baltic Sea bottom-water exchange is dependent on frequency of storms that force salty oceanic water over the sills at the Danish Sounds to the Baltic Sea from the North Sea. As this salty water oxygenates the Baltic Sea bottom, some of the lower salinity, low $\mathrm{N}: \mathrm{P}$ ratio, $\mathrm{P}$-enriched anoxic bottom waters are transported to the surface (Nehring 1981) and, as a result, intense cyanobacterial blooms develop over the next several years (Kahru et al. 2000, Kiirikki et al. 2001).

Superimposed on this large-scale forcing cycle, which has significant interannual variability in the Baltic Sea, $P$ effects on growth and $\mathrm{N}_{2}$ fixation of cyanobacteria are observed regionally and locally, at short time scales. Certain Baltic Sea regions are hydrodynamically more active than others, and susceptible to vertical water exchange such as upwelling and frontal transport that act as 'P pumps' into the surface waters (Kononen et al. 1996, Pavelson et al. 1997, Vahtera et al. 2005). These locations are often sites of intensive cyanobacterial growth. Cyanobacterial populations in the euphotic surface waters are likely to experience $\mathrm{P}$ depletion repeatedly over the growing season, depending on hydrodynamic conditions and how far they have advected from these P 'hotspots'. P regeneration within Nodularia spumigena aggregates may be an important mechanism by which blooms are maintained (Hagström et al. 2001). There is a general agreement that $\mathrm{P}$ regulates cyanobacterial bloom intensities in the Baltic Sea over interannual, basinwide scales (Kahru et al. 2000, Kiirikki et al. 2001).
However, estimates on the regulation and limitation of cyanobacterial growth and $\mathrm{N}_{2}$ fixation in the Baltic Sea vary over time scales of hours to days (Wallström et al. 1992, Stal et al. 1999, Rydin et al. 2002, Moisander et al. 2003).

The goal of this study was to investigate short-term effects of $\mathrm{P}$ on the growth and $\mathrm{N}_{2}$ fixation of Baltic Sea cyanobacteria, to better understand regional differences in bloom intensities and mechanisms for bloom maintenance. In order to study regulation of the nitrogenase proteins over the diel cycle, we additionally investigated potential changes in the quantity and size of the 2 cofactors of the nitrogenase enzyme (Fe and MoFe proteins) in response to darkness. This information is essential for predicting and modeling cyanobacterial bloom formation and $\mathrm{N}_{2}$ fixation based on $\mathrm{P}$ availability in the Baltic Sea.

\section{MATERIALS AND METHODS}

Baltic Sea field studies. Field studies were carried out onboard RV 'Aranda' (Finnish Institute of Marine Research) in 2002 and 2003. The study area was located in the Gulf of Finland and the Northern Baltic Proper (Table 1). Diel cycles in the field were studied through incubation experiments on deck using Baltic seawater (Expts 02A, 02B, 03A, 03B), and by sampling directly from the sea (Expt An03), both types of samples defined as 'field samples' (Table 1). In the incubation experiments, surface water was collected from $~ 1 \mathrm{~m}$ depth using a pump (in 2002), or a 301 water sampler (2003). All of the water collected was mixed in a $100 \mathrm{l}$ container on deck, and then $14 \mathrm{l}$ (2002) or $17 \mathrm{l}$ (2003) were poured into each of six 201 pre-cleaned $(0.01 \mathrm{~N} \mathrm{HCl}$ and deionized water) Cubitainers (Hedwin). Cubitainers are containers made of polyethylene and are approximately $85 \%$ transparent to incident photosynthetically active irradiation (PAR). The

Table 1. Diel experiments with natural communities in the Baltic Sea. Temperature, salinity, and nutrients are from 1.5 to $2 \mathrm{~m}$ depth

\begin{tabular}{|c|c|c|c|c|c|c|c|c|c|}
\hline Expt & Date & Type & Station & Location & $\begin{array}{c}\text { Treatment } \\
\text { or depth }\end{array}$ & $\begin{array}{l}\text { Temp. } \\
\left({ }^{\circ} \mathrm{C}\right)\end{array}$ & Salinity & $\begin{array}{l}\text { DIN } \\
(\mu \mathrm{M})\end{array}$ & $\begin{array}{l}\text { DIP } \\
(\mu \mathrm{M})\end{array}$ \\
\hline $02 \mathrm{~A}$ & $\begin{array}{l}\text { Sampled } 15 \text { July } 2002 \\
\text { Expt 16-17 July } 2002\end{array}$ & Cubitainer & H02_A1_4 & $\begin{array}{l}59.2946^{\circ} \mathrm{N} \\
23.0215^{\circ} \mathrm{E}\end{array}$ & Control, P & 18.3 & 5.6 & $0.12^{\mathrm{a}}$ & $0.2^{\mathrm{a}}$ \\
\hline 02B & $\begin{array}{l}\text { Sampled } 18 \text { July } 2002 \\
\text { Expt } 22-23 \text { July } 2002\end{array}$ & Cubitainer & H02_EA & $\begin{array}{l}59.2210^{\circ} \mathrm{N} \\
22.4309^{\circ} \mathrm{E}\end{array}$ & Control, P & 20.0 & 5.6 & 0.14 & 0.16 \\
\hline 03A & $\begin{array}{l}\text { Sampled } 16 \text { July } 2003 \\
\text { Expt } 19-20 \text { July } 2003\end{array}$ & Cubitainer & LL3A & $\begin{array}{l}60.0403^{\circ} \mathrm{N} \\
26.2079^{\circ} \mathrm{E}\end{array}$ & Control, P & 16.7 & 6.2 & & \\
\hline 03B & $\begin{array}{l}\text { Sampled } 14 \text { July } 2003 \\
\text { Expt } 15-16 \text { July } 2003\end{array}$ & Cubitainer & JML & $\begin{array}{l}59.3506^{\circ} \mathrm{N} \\
23.3766^{\circ} \mathrm{E}\end{array}$ & Control, P & 19.3 & 5.2 & & \\
\hline An03 & 24-25 July 2003 & Rosette & JML & $\begin{array}{l}59.3506^{\circ} \mathrm{N} \\
23.3766^{\circ} \mathrm{E}\end{array}$ & $0 \mathrm{~m}, 8 \mathrm{~m}$ & $20.2-21.1$ & $5.4-5.5$ & & \\
\hline
\end{tabular}


Cubitainers were inoculated with a concentrated phytoplankton sample, consisting mostly of the filamentous cyanobacteria collected by vertical tows from the 0 to $10 \mathrm{~m}$ surface layer using a $100 \mu \mathrm{m}$ zooplankton net (2.6 1 in 2002 and 11 in 2003). Three Cubitainers received a phosphorus addition (as $\mathrm{K}_{2} \mathrm{HPO}_{4} ; 2 \mu \mathrm{M}$ final concentration), while the other 3 were controls. The Cubitainers were placed in tubs on the ship deck under natural irradiance with flowing surface seawater for temperature control. They were shaded with screening to alleviate photoinhibition by reducing PAR by $30 \%$. Measurements were started within 16 to $88 \mathrm{~h}$ of the $\mathrm{P}$ addition. In each experiment, the diel measurements were initiated at 06:00 h. A sub-sample from the Cubitainers was collected every $3 \mathrm{~h}$ over the diel cycle in order to determine the rates of $\mathrm{N}_{2}$ fixation using the acetylene reduction technique (AR). For immunoblotting of the nitrogenase enzyme, a subsample was collected every $3 \mathrm{~h}$ during the day and every 1 to $1.5 \mathrm{~h}$ at night. Sub-samples were also preserved in Lugol's solution for microscopic observations of community structure.

In addition to the incubation experiments, diurnal patterns of $\mathrm{N}_{2}$ fixation were assessed in samples collected directly from the Baltic Sea at each time point of the diel study. A $24 \mathrm{~h}$ anchor station experiment was conducted on 24-25 July 2003 (Table 1, Expt An03), during which samples for $\mathrm{N}_{2}$-fixation measurements were collected from $1 \mathrm{~m}$ and $8 \mathrm{~m}$ depths every $3 \mathrm{~h}$ with Niskin bottles. Samples for immunoblotting during this experiment were collected every $3 \mathrm{~h}$ during the day and every $1 \mathrm{~h}$ at night for $24 \mathrm{~h}$. Additionally, CTD profiles and vertical profiles of PAR were obtained on each sampling occasion.

Culture studies. In order to study diel patterns of $\mathrm{N}_{2}$ fixation in Nodularia spumigena in more detail, a diel experiment was carried out in the laboratory with N. spumigena strain FL2f isolated from the Baltic Sea (Moisander et al. 2002). The cultures were kept on a 15:9 h light:dark cycle. The experimental cultures were grown in a 11 volume in duplicate 21 flasks with constant aeration provided through a $0.2 \mu \mathrm{m}$ filter and kept in an incubator at 27 to $30^{\circ} \mathrm{C}$ and $200 \mu \mathrm{mol} \mathrm{m}{ }^{-2} \mathrm{~s}^{-1}$ PAR. The strains were grown in Z8 media (Rippka 1988), with combined nitrogen omitted and salts added at $0.15 \mathrm{M} \mathrm{NaCl}$ and $0.015 \mathrm{M} \mathrm{MgSO}_{4}$ (final concentrations) for optimal growth (Moisander et al. 2002). Samples for the following assays were collected every $2 \mathrm{~h}$ during the diel experiments: $\mathrm{CO}_{2}$ fixation ( $\mathrm{NaH}^{14} \mathrm{CO}_{3}$ incorporation), $\mathrm{N}_{2}$ fixation (acetylene reduction assay), abundance of the $\mathrm{Fe}$ and $\mathrm{MoFe}$ proteins in the nitrogenase enzyme (SDS-PAGE and immunoblotting with $\mathrm{Fe}$ and MoFe protein antibodies), chlorophyll a (chl a) concentration, and dissolved inorganic carbon (DIC) concentration.
Analytical methods. Acetylene reduction assay (AR): $\mathrm{N}_{2}$-fixation activity was measured every $2 \mathrm{~h}$ in cultures and every $3 \mathrm{~h}$ in field samples. In the field studies, 1 AR measurement was taken from each Cubitainer (triplicate Cubitainers per treatment) or in triplicate from the Niskin bottle (Expt An03), whereby a $90 \mathrm{ml}$ sample was incubated in $117 \mathrm{ml}$ serum vials capped with red rubber serum stoppers. In culture experiments, duplicate AR measurements were made from 2 independent culture flasks each, whereby $8 \mathrm{ml}$ of culture was transferred into $13 \mathrm{ml}$ Exetainer tubes (Labco) and tubes were capped with serum screw caps. Acetylene was generated from calcium carbide, and 9 or $2 \mathrm{ml}$ acetylene was injected with a syringe into each vial through the liquid phase in field and culture experiments, respectively. Next, the incubation vials were shaken for $\sim 10 \mathrm{~s}$. AR vials in the field were incubated for $3 \mathrm{~h}$ in the flowing surface water bath on the deck, while the AR vials in culture experiments were incubated for $2 \mathrm{~h}$ in the culture incubator. At the end of the incubation, tubes and flasks were shaken for $\sim 20 \mathrm{~s}$, and sub-samples of the headspace were collected into evacuated Vacutainers (Becton-Dickinson). To avoid potential trace ethylene contamination, Vacutainers were opened, aerated overnight, recapped, and manually re-evacuated using a $60 \mathrm{ml}$ syringe prior to use. Ethylene content was measured using a Shimadzu GC-9A gas chromatograph equipped with a flame ionization detector and a Poropak $\mathrm{T}$ stainless steel column at $80^{\circ} \mathrm{C}$, using ultrapure $\mathrm{N}_{2}$ as a carrier gas. The gas chromatograph was calibrated daily using a standard curve constructed from ethylene (National Welders). Rates in blanks with Milli-Q water were subtracted from the rates in samples.

SDS-PAGE and western blotting: Cyanobacteria were filtered on $47 \mathrm{~mm}$ diameter, $5 \mu \mathrm{m}$ pore-size Durapore filters (Millipore), snap frozen in liquid nitrogen, and stored at $-80^{\circ} \mathrm{C}$. The samples were extracted in Laemmli's buffer (Laemmli 1970), sonicated twice for $1 \mathrm{~min}$ in ice with a tip sonicator (with a minimum $10 \mathrm{~min}$ cooling period in ice between sonications), and heated to between 90 and $95^{\circ} \mathrm{C}$ for $5 \mathrm{~min}$. Cell debris was removed by centrifugation, and the supernatant was transferred into a new tube and stored at $-80^{\circ} \mathrm{C}$. Total protein concentrations were determined using the BioRad RCDC kit (Bio-Rad). For each experiment, a similar amount of protein for each time point was loaded on Bio-Rad polyacrylamide Tris- $\mathrm{HCl}$ ready-gels (10\% resolving, $4 \%$ stacking gel). The amount of protein loaded varied from 7.5 to $20 \mu \mathrm{g}$, but was the same within each experiment. Wide range, colored molecular weight markers (6500 to $205000 \mathrm{kDa}$ ) were used (Sigma). Purified $\mathrm{Fe}$ and MoFe proteins from Azotobacter vinelandii (Av2 and Av1, respectively), donated by G. Roberts (University of Wisconsin, Madi- 
son), were used as controls. Av1 and Av2 served as positive controls when blotted with a specific antibody, and as negative controls when blotted with a non-specific antibody. Proteins were transferred onto $0.45 \mu \mathrm{m}$ nitrocellulose membranes using the Bio-Rad minicell transfer unit with cooling. Membranes were frozen $\left(-20^{\circ} \mathrm{C}\right)$ until blotting. For immunoblotting, membranes were first incubated for $1 \mathrm{~h}$ with TTBS $(0.5 \mathrm{M} \mathrm{NaCl}, 20 \mathrm{mM}$ Tris base, $0.1 \%$ Tween 20, pH 9.0), then blocked for $2 \mathrm{~h}$ in $2 \%$ bovine serum albumin in TTBS $(\mathrm{pH} \mathrm{7.5)}$ and washed twice for 5 min with TTBS ( $\mathrm{pH} 7.5$ ). Next, the membranes were incubated for $1 \mathrm{~h}$ with one of the primary antibodies in TTBS and immediately washed twice for 5 min with TTBS ( $\mathrm{pH}$ 7.5). The primary antibodies were donated by P. Ludden (University of Wisconsin, Madison) and were generated against dinitrogenase (MoFe protein) from Rhodospirillum rubrum and dinitrogenase reductase (Fe protein) from $R$. rubrum and $A$. vinelandii. The membranes were then incubated with an anti-rabbit IgG secondary antibody with alkaline phosphatase conjugate (Sigma) for $1 \mathrm{~h}$ and washed twice for 5 min with TTBS (pH 7.5), and finally twice for $5 \mathrm{~min}$ with TBS (TTBS without Tween 20, $\mathrm{pH}$ 7.5). The bound antibodies were visualized using a Sigma BCIP/NBT liquid substrate system alkaline phosphatase detection kit according to the manufacturer's instructions. The blots were recorded using a Bio-Rad image analysis system and stored at $-20^{\circ} \mathrm{C}$.

Chl a, cyanobacterial abundance: For chl a analysis, samples were filtered onto Whatman GF/F filters, blotted dry on a paper towel, wrapped in aluminum foil, and frozen at $-20^{\circ} \mathrm{C}$. For determination of the chl a concentration in culture samples, the filters were extracted using a $90 \%$ acetone, $10 \%$ water mixture. Each sample was sonicated twice for $1 \mathrm{~min}$ in ice and kept at $-20^{\circ} \mathrm{C}$ in the dark overnight. The extract was cleared by filtering through Whatman GF/F filters and fluorescence was detected using a Turner TD-700 fluorometer (Welschmeyer 1994). For chl a determination in field populations (deck incubations and direct sampling from the sea), the filters were extracted with $96 \%$ ethanol for $>18 \mathrm{~h}$ at room temperature in the dark (Baltic Marine Environment Protection Commission 1988) and measured using a Perkin-Elmer LS-2 spectrofluorometer (Wellesley) at $662 \mathrm{~nm}$. For the determination of cyanobacterial abundances in the field samples, 50 to $100 \mathrm{ml}$ sample water was preserved with Lugol's solution and stored in the dark. The lengths of at least 50 filaments of each cyanobacterial taxon were measured and counted on a SedgewickRafter counting cell using a Zeiss Axioplan 2 (Thornwood) microscope at $200 \times$ magnification.

$\mathrm{CO}_{2}$-fixation, dissolved inorganic carbon (DIC): Photosynthetic activity in culture experiments was determined using the ${ }^{14} \mathrm{C}$ incorporation method (Stee- mann Nielsen 1952). From each culture, $5 \mathrm{ml}$ was transferred into $20 \mathrm{ml}$ liquid scintillation vials and $50 \mu \mathrm{l}$ $\mathrm{NaH}^{14} \mathrm{CO}_{3}$ was added to give a final activity of approximately $0.02 \mu \mathrm{Ci} \mathrm{ml}^{-1}$. At each time point, the actual activity was determined parallel to the samples from vials containing $50 \mu \mathrm{l} \mathrm{NaH}^{14} \mathrm{CO}_{3}$ and $50 \mu \mathrm{l}$ phenethylamine. The $\mathrm{CO}_{2}$ fixation measurements were carried out in duplicate for each of the 2 culture flasks per strain. One additional vial was incubated in the dark at each time point, and the dark ${ }^{14} \mathrm{C}$ incorporation was subtracted from light values at that time point. The vials were incubated for $2 \mathrm{~h}$ beside the culture flasks in the incubator. After incubation, the contents of the vials were filtered on Whatman GF/F glass-fiber filters, and unincorporated ${ }^{14} \mathrm{C}$ was removed from the filters by fuming them in a concentrated $\mathrm{HCl}$ atmosphere for at least $1 \mathrm{~h}$ in the dark. The filters were air-dried overnight and placed in $7 \mathrm{ml}$ liquid scintillation vials with $5 \mathrm{ml}$ of liquid scintillation cocktail (Ecolume). Radioactivity was measured using a Beckman LS5000TD liquid scintillation counter (Fullerton). Counts per min were converted to disintegrations per min using a quench curve constructed by a ${ }^{14} \mathrm{C}$ toluene standard. The DIC concentrations used in calculations of $\mathrm{CO}_{2}$ fixation were determined at each time point. Samples for DIC were collected in $7 \mathrm{ml}$ tubes sealed without headspace and stored at $4^{\circ} \mathrm{C}$ until measurement with a Shimadzu TOC-5000A analyzer.

Physical measurements in the field: Vertical profiles of PAR in the water column were detected using an upward facing LI-COR (Lincoln) quantum sensor. Incident irradiance in air was measured using duplicate quantum sensors located on each side of the ship. Salinity and temperature profiles were obtained with a Seabird 911plus profiler (Bellevue). Nutrients onboard RV 'Aranda' were measured using an autoanalyzer following the guidelines of the Baltic Sea Monitoring Programme (Baltic Marine Environment Protection Commission 1983).

Statistical methods: Linear regression analysis (SPSS for Windows) was performed for pooled $\mathrm{N}_{2}$ fixation (acetylene reduction) rate and chl a data from the field study. The midnight datapoint in $\mathrm{N}_{2}$ fixation was a large outlier in Expt 03B and was removed from the analysis.

\section{RESULTS}

The cyanobacterial community in the Baltic Sea was dominated by both Nodularia spumigena and Aphanizomenon sp. in 2002 and by Aphanizomenon sp. in 2003. Both cyanobacteria were present in the community during 2002 and 2003, with variable abundances among experiments (Fig. 1). Anabaena spp. were 
present in the community in both years but at lower abundances than $N$. spumigena and Aphanizomenon sp. (Fig. 1). The ratio of DIN:DIP (in moles) was less than 1.3 in 2002, indicating that nitrogen limited phytoplankton growth (Table 1). Highest $\mathrm{N}_{2}$ fixation rates were detected in incubations that started between 06:00 and 15:00 h (09:00 to 15:00 h in 2002, and $06: 00$ to $09: 00 \mathrm{~h}$ or 12:00 to $15: 00 \mathrm{~h}$ in 2003), while the lowest rates were observed in incubations that started between 21:00 and 03:00 h (Fig. 2). $\mathrm{N}_{2}$ fixation rates in complete darkness (00:00 h time point) were 16 to $61 \%$ of the maximum daytime rates. In one experiment, there was a second peak in nitrogenase activity at midnight (Fig. 2D). In order to investigate the time scale in P stimulation during the 4 diel incubation experiments, the time from $\mathrm{P}$ addition to the beginning of the diel measurements was varied. In one experiment each year, the diel measurements were started 16 to $20 \mathrm{~h}$ after the experimental water was collected (Fig. 2A,C). In these experiments, P addition had only a minor visible effect on chl a concentration or $\mathrm{N}_{2}$ fixation over the diel cycle. In a second experiment in 2002 and 2003, diel measurements were started after the water with added $\mathrm{P}$ had been incubated for $88 \mathrm{~h}$ (2002) or $64 \mathrm{~h}$ (2003) (Fig. 2B,D). In both of these experiments, $\mathrm{N}_{2}$ fixation and $\mathrm{chl} a$ concentration were
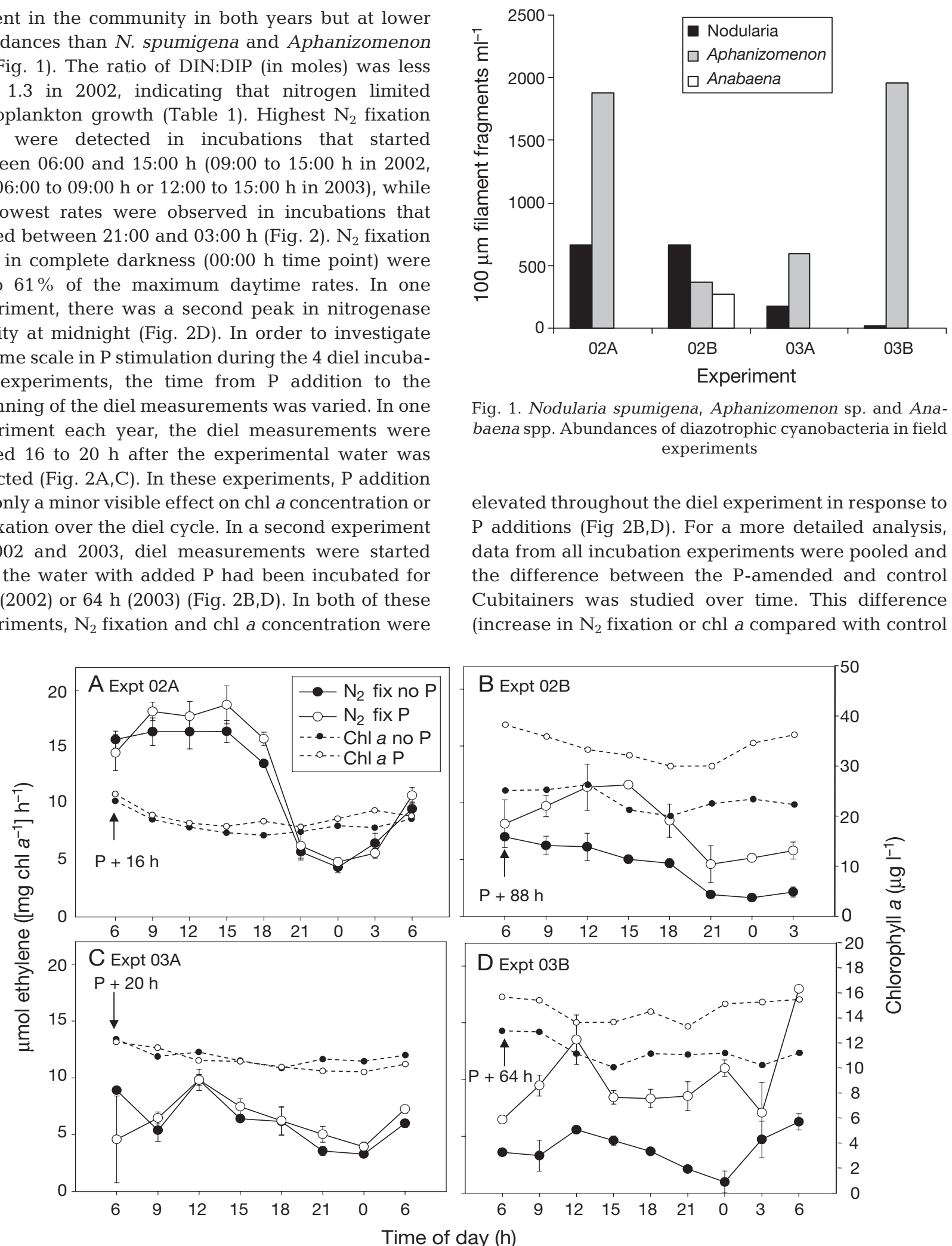

Fig. 1. Nodularia spumigena, Aphanizomenon sp. and Anabaena spp. Abundances of diazotrophic cyanobacteria in field experiments

elevated throughout the diel experiment in response to $\mathrm{P}$ additions (Fig 2B,D). For a more detailed analysis, data from all incubation experiments were pooled and the difference between the P-amended and control Cubitainers was studied over time. This difference (increase in $\mathrm{N}_{2}$ fixation or chl a compared with control

Fig. 2. $\mathrm{N}_{2}$ fixation rates (acetylene reduction) and chl a concentrations in Baltic Sea diel incubation experiments with $\mathrm{P}$ additions. Time from addition of $\mathrm{P}$ to the first $\mathrm{N}_{2}$ fixation measurement varied as indicated by arrows. (A) 16-17 July 2002 (Expt $02 \mathrm{~A}$ ); (B) 22-23 July 2002 (Expt 02B); (C) 15-16 July 2003 (Expt 03A); (D) 19-20 July 2003 (Expt 03B). Error bars: \pm SD. For (C) period between final 2 measurements is $6 \mathrm{~h}$ 
[\% control]) represents the new activity or growth that occurred in response to $\mathrm{P}$. There was a significant positive relationship (linear regression) between time and the 'new $\mathrm{N}_{2}$ fixation' $\left(\mathrm{R}^{2}=0.54, \mathrm{p}=0.000\right)$ and 'new chl $a^{\prime}\left(\mathrm{R}^{2}=0.79, \mathrm{p}=0.000\right)$ (Fig. 3). Cyanobacterial numbers of all taxa (N. spumigena, Aphanizomenon sp., Anabaena spp.) increased during the diel experiment that had a $64 \mathrm{~h}$ pre-incubation with P (Fig. 4).

Very calm, sunny conditions prevailed during the anchor station experiment in 2003 (An03) (Fig. 5). Aphanizomenon sp. was the only diazotroph detected in microscopic observations at this station. Nitrogen fixation continued at both 1 and $8 \mathrm{~m}$ depths throughout the diel cycle (Fig. 5A), and trailed the irradiance intensity in the water column and air (Fig. 5A,B). There was a deepening of the thermocline during the day and gradual shallowing again at night (Fig. 5C).

The Fe protein was detected throughout the diel cycle in both the Cubitainers and the anchor station experiment (Fig. 6). No changes over the diel cycle in molecular weight (MW) or consistent changes in the abundance of the nitrogenase $\mathrm{Fe}$ protein in immunoblots were observed either in the Cubitainer incubations or samples taken directly from the sea (Fig. 5). A second, higher MW band appeared sporadically in an experiment in which inhibitors were tested (data not shown). In the Baltic Sea field samples, the MoFe protein had a very weak antibody binding capacity and blots did not produce good results.

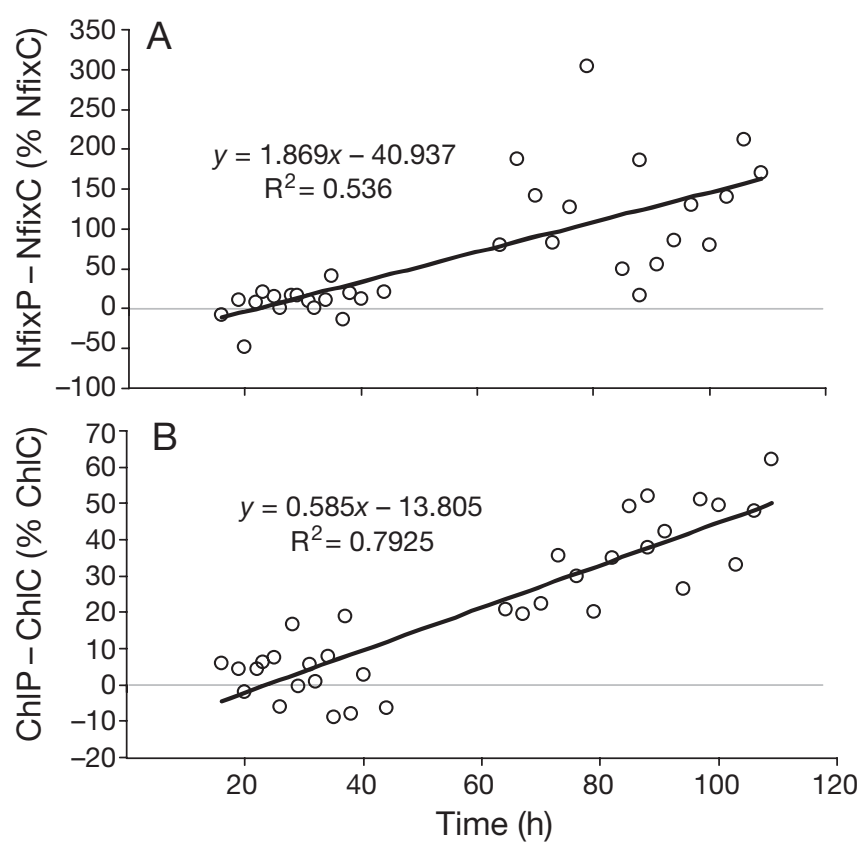

Fig. 3. Linear regression between (A) 'new $\mathrm{N}_{2}$ fixation' and time; and (B) 'new chl $a$ ' and time, in response to P. Data from 4 enrichment experiments were pooled; $y$-axis unit is the difference between $\mathrm{P}$ treatment (suffix P) and control (suffix C) (\% of control)

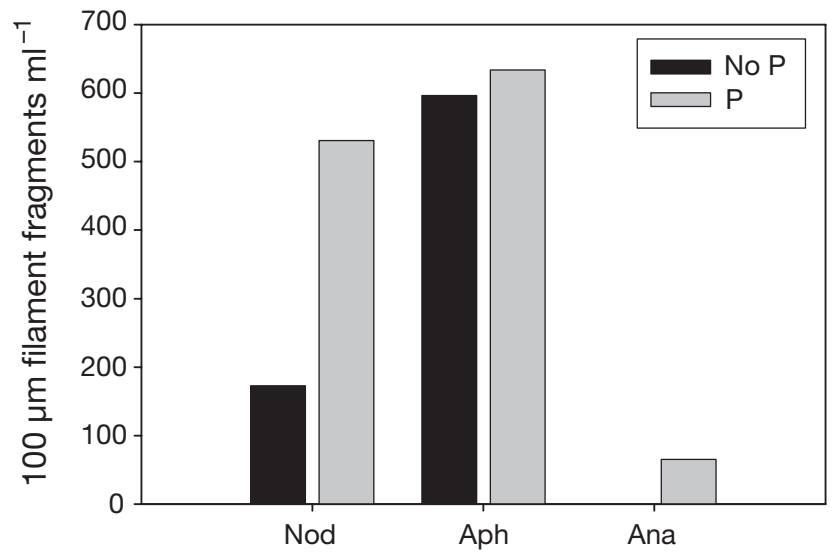

Fig. 4. Nodularia spumigena (Nod), Aphanizomenon sp. (Aph) and Anabaena spp. (Ana). Abundances of diazotrophic cyanobacteria at the end of diel Expt 03B. No P: control treatment; P: P added

A culture experiment was carried out with a Nodularia spumigena strain to investigate its diel cycle in $\mathrm{N}_{2}$ and $\mathrm{CO}_{2}$ fixation and abundances and motility of nitrogenase proteins, in order to compare these with the field data (Fig. 7). Carbon fixation was tightly coupled with light, while $\mathrm{N}_{2}$ fixation continued throughout the diel cycle, albeit at reduced rates in the dark. The $\mathrm{N}_{2}$ fixation rates in the dark were 21 to $45 \%$ of maximum rates in the light. Both $\mathrm{Fe}$ and MoFe proteins remained present throughout the diel cycle, with no detectable changes in abundance or MW. The MoFe protein from $N$. spumigena cultures had a weak binding capacity with the antibody and resolved as 3 bands, while the MoFe protein from Anabaena aphanizomenoides and Anabaenopsis sp. (both isolated from the Neuse River Estuary, North Carolina) resolved as 2 bands and had a much stronger binding capacity with the antibody (data not shown). DIC concentration gradually decreased during the day, but by the following morning had returned to the same level as the morning before.

\section{DISCUSSION}

The phosphorus effect on $\mathrm{N}_{2}$ fixation and chl a was striking and consistent in diel experiments that started 64 and $88 \mathrm{~h}$ after the $\mathrm{P}$ addition (Expts 03B and 02B, respectively). When all the data were pooled, it became apparent that $\mathrm{P}$ started to affect the population growth and $\mathrm{N}_{2}$ fixation rates earlier than $64 \mathrm{~h}$ of $\mathrm{P}$ addition (Fig. 3). Chl a concentrations and cyanobacterial numbers paralleled $\mathrm{N}_{2}$ fixation rates; therefore, it was not clear whether P stimulated growth, $\mathrm{N}_{2}$ fixation, or both. Potentially, P could directly enhance nitrogenase gene mRNA copy numbers and consequently $\mathrm{N}_{2}$ fixa- 
tion rates per cell. At $109 \mathrm{~h}$, 'new $\mathrm{N}_{2}$ fixation' ( $\mathrm{N}_{2}$-fixation increase in response to $\mathrm{P}$ ) was showing signs of reaching a plateau, but both 'new' $\mathrm{N}_{2}$ fixation and chl a concentration continued to increase $4.5 \mathrm{~d}$ after the $\mathrm{P}$ amendment. It is likely that the continuously increasing chl a partially represents production from recycled nitrogen that became available to the non-diazotrophic portion of the community from cyanobacterial exudates. The time relationship of new $\mathrm{N}_{2}$ fixation and growth in response to $\mathrm{P}$ is useful when estimating the potential for enhancement of $\mathrm{N}_{2}$ fixation in the Baltic Sea after a $P$ pulse, typical of upwelling or other mixing events. In 2002 there was on average a doubling (1.1fold increase) in $\mathrm{N}_{2}$ fixation in the period 88 to $109 \mathrm{~h}$ after $\mathrm{P}$ addition. In 2003, there was on average a 2.4fold increase in $\mathrm{N}_{2}$ fixation 64 to $88 \mathrm{~h}$ after $\mathrm{P}$ addition. At individual time points, differences between the $\mathrm{P}$ treatment and control were even higher. In contrast, the chl a concentrations had a lower slope value for increase under $\mathrm{P}$ amendment than did $\mathrm{N}_{2}$ fixation rates, suggesting that the increase in chl a was less than the increase in $\mathrm{N}_{2}$ fixation. Taken together, the data suggest there is a potential for up to a $300 \%$ (3fold) increase in $\mathrm{N}_{2}$ fixation and up to a $62 \%$ (0.6-fold) increase in chl a in Baltic Sea cyanobacterial blooms within $4.5 \mathrm{~d}$ in response to a single, saturating $\mathrm{P}$ pulse.

While only few studies have measured cyanobacterial $\mathrm{N}_{2}$ fixation rates in response to $\mathrm{P}$ in the Baltic Sea, more data exist on the effects of $\mathrm{P}$ on their growth. In nutrient addition experiments and mesoscale field studies, $\mathrm{P}$ often stimulated growth of $\mathrm{N}_{2}$-fixing cyanobacteria; however, other limitations were also apparent (Wallström et al. 1992, Kononen et al. 1996, Stal et al. 1999, Moisander et al. 2003, Vahtera et al. 2005). In a Baltic Sea mesocosm experiment, Nodularia spumigena growth rates were stimulated from 9.0 to $3.6 \mathrm{~d}^{-1}$ when $\mathrm{P}$ was added over a $14 \mathrm{~d}$ period (Wallström et al. 1992). In another mesocosm experiment with Northwest Baltic Proper $\mathrm{N}_{2}$-fixing cyanobacteria, chl a increased 2- to 3-fold in response to P over a $25 \mathrm{~d}$ period ( $\mathrm{P}$ amended every $4 \mathrm{~d}$ ) with a linear regression similar to that obtained in this study (Rydin et al. 2002). Collectively, these studies suggest that P commonly limits both $\mathrm{N}_{2}$ fixation and growth of cyanobacteria in the Baltic Sea. The magnitude of the in situ response to $P$ shown in this study is of importance when estimating the impact of localized P pulses to existing cyanobacterial populations. In addition to P limitation, iron limitation and sulfate inhibition were previously proposed as controls of $\mathrm{N}_{2}$ fixation in Baltic Sea cyanobacteria (Stal et al. 1999, Rydin et al. 2002).

In this study, the peak in nitrogenase activity in the Baltic Sea occurred between 09:00 and 15:00 h, which is similar to that observed in some previous studies (Vuorio et al. 1978, Evans et al. 2000) but at an earlier time of the
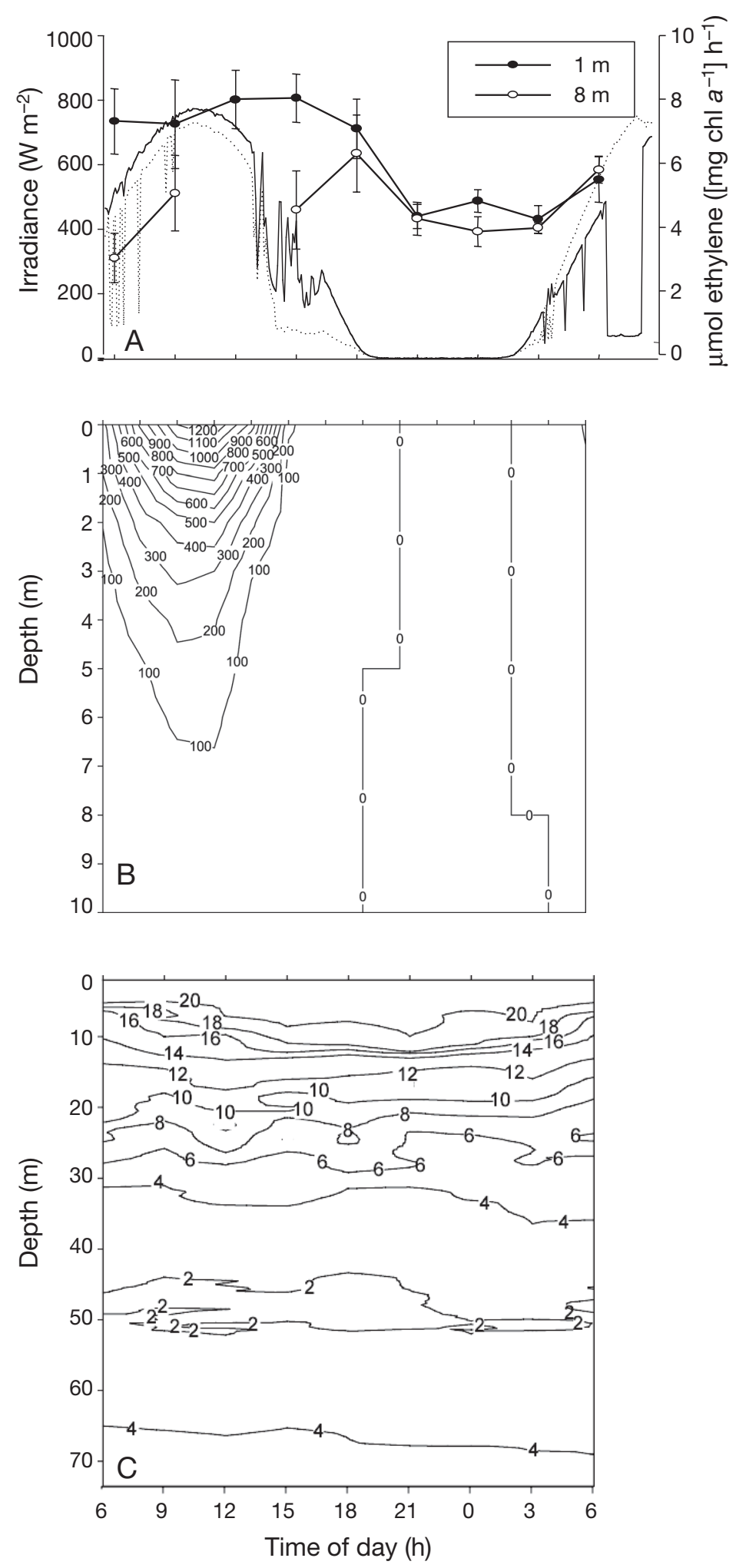

Fig. 5. Anchor station (An03) on 24-25 July 2003. (A) $\mathrm{N}_{2}$ fixation ( $\mu \mathrm{mol}$ ethylene [mg chl $\left.a^{-1}\right] \mathrm{h}^{-1}$ ) (circles) measured from water sampled from 1 and $8 \mathrm{~m}$ depths. Daily incident irradiance $\left(\mathrm{W} \mathrm{m}^{-2}\right)$ measured on each side of the ship (solid and dotted lines with no symbols); (B) irradiance in the water column $\left(\mu \mathrm{mol} \mathrm{m}{ }^{-2} \mathrm{~s}^{-1}\right)$; and $(\mathrm{C})$ temperature $\left({ }^{\circ} \mathrm{C}\right)$ in the water column 


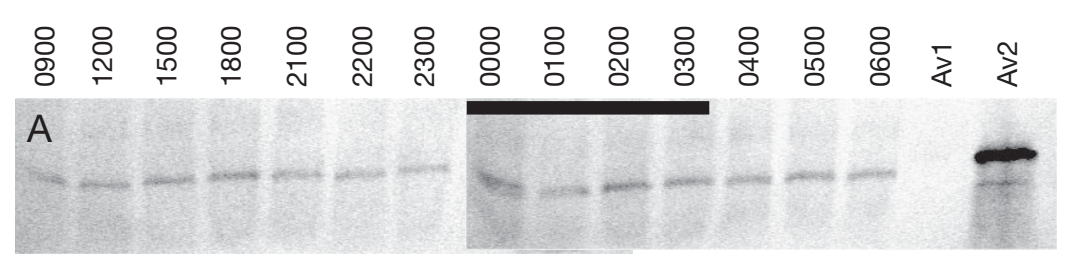

at this station, whereas Nodularia spumigena was not detected in microscopic observations. The peak in nitrogenase activity lagged behind the peak in irradiance intensity at the anchor station, providing evidence for light dependence of $\mathrm{N}_{2}$ fixation in Aphanizomenon sp. The anchor station experiment demonstrated the ability of natural populations of Aphanizomenon sp. to continue to fix $\mathrm{N}_{2}$ at a constant rate long after irradiance levels are drastically reduced, indicating a reliance on carbohydrate stores generated during the day.

In both the field samples (including the anchor station at which Aphanizomenon sp. was the only diazotroph

day than reported by Gallon et al. (2002). These differences may partially reflect cloudiness during the days of measurement. $\mathrm{N}_{2}$ fixation continued throughout the dark period, as reported in other studies of the Baltic Sea in which the dominating genus was mostly Aphanizomenon (Vuorio et al. 1978, Stal \& Walsby 1998, Evans et al. 2000, Gallon et al. 2002). Nodularia spumigena and Aphanizomenon sp. fixed $\mathrm{N}_{2}$ in the dark at 68 to $97 \%$ and 31 to $33 \%$ of maximum rates in light, respectively (Evans et al. 2000). In this study, the $\mathrm{N}_{2}$ fixation rates for N. spumigena culture were slightly lower, 21 to $45 \%$ of maximum rates in the light. In field samples, dark fixation rates ranged from 26 to $61 \%$ of maximum rates in the light. These rates are higher than is typical of heterocystous cyanobacteria. In identical culture experiments, and under a $15: 9 \mathrm{~h}$ light:dark cycle, $\mathrm{N}_{2}$ fixation in the heterocystous cyanobacteria Anabaena aphanizomenoides and Anabaenopsis sp. isolated from the Neuse River Estuary was significantly more reduced in the dark (data not shown). In the N. spumigena cultures from this study, $\mathrm{CO}_{2}$ and $\mathrm{N}_{2}$ fixation continued at more or less constant rates during the light period, exhibiting no lag periods or exhaustion of resources for either process. Nodularia spumigena may be able to store energy in the form of carbohydrates more effectively than other heterocystous cyanobacteria, allowing it to continue $\mathrm{N}_{2}$ fixation at high rates throughout the dark period (Evans et al. 2000). Alternatively, it may be able to utilize other mechanisms for energy generation in the dark.

Nitrogen fixation rates at the anchor station at $8 \mathrm{~m}$ depth were 45 to $105 \%$ of the rates in the surface water, and were detectable throughout the night. Interestingly, the diel pattern at $8 \mathrm{~m}$ depth was still present even though irradiance at this depth was only 2 to $4 \%$ of the surface irradiance, varying between 0.3 and $61 \mu \mathrm{mol} \mathrm{m} \mathrm{m}^{-2} \mathrm{~s}^{-1}$ during the day (06:00 to 23:00 h) (Fig. 5A). Aphanizomenon sp. was present detected) and Nodularia spumigena cultures, dinitrogenase reductase (Fe protein) and dinitrogenase (MoFe protein) ( $N$. spumigena cultures only) remained present throughout the diel cycle, and no apparent or consistent changes in intensities or MW were observed. These results contrast those of another Baltic Sea study, in which a reduction in the Fe protein intensity was reported during the night (Gallon et al. 2002). Some diazotrophs, including some cyanobacteria, regulate nitrogenase activity in response to environmental factors such as $\mathrm{NH}_{4}{ }^{+}$or darkness through structural modifications of the Fe protein (Ludden \& Burris 1978, Zehr et al. 1993, Nordlund 2000). This modification often occurs through ADP-ribosylation and appears as a slower migrating, inactive form of the Fe protein in SDS-PAGE. The lack of change in motility of the nitrogenase proteins during reduced $\mathrm{N}_{2}$-fixation activities in the dark suggests that Baltic Sea N. spumigena and Aphanizomenon sp. do not use size modification as a mechanism to regulate their nitrogenase activity in response to darkness, or that the modification is too labile to be detected. The absence of this mechanism in these heterocystous cyanobacteria is supported by a prior study with Anabaena variabilis in which the ribosylation pathway enzymes were not found to be functional and a secondary band was not present (Durner et al. 1994). Furthermore, ADP ribosylation has not been found in all non-cyanobacterial diazotrophs studied. For example, no size modification of the Fe protein was observed for Rhodobacter sphaeroides in response to either $\mathrm{NH}_{4}{ }^{+}$or darkness (Yoch et al. 1988).

Most environmental nitrogenase enzyme studies have focused on the Fe protein, while the MoFe protein has received considerably less attention. In this study, we obtained novel information on the MoFe protein of Nodularia spumigena. Structure of the Fe protein is relatively conserved among diazotrophs as 

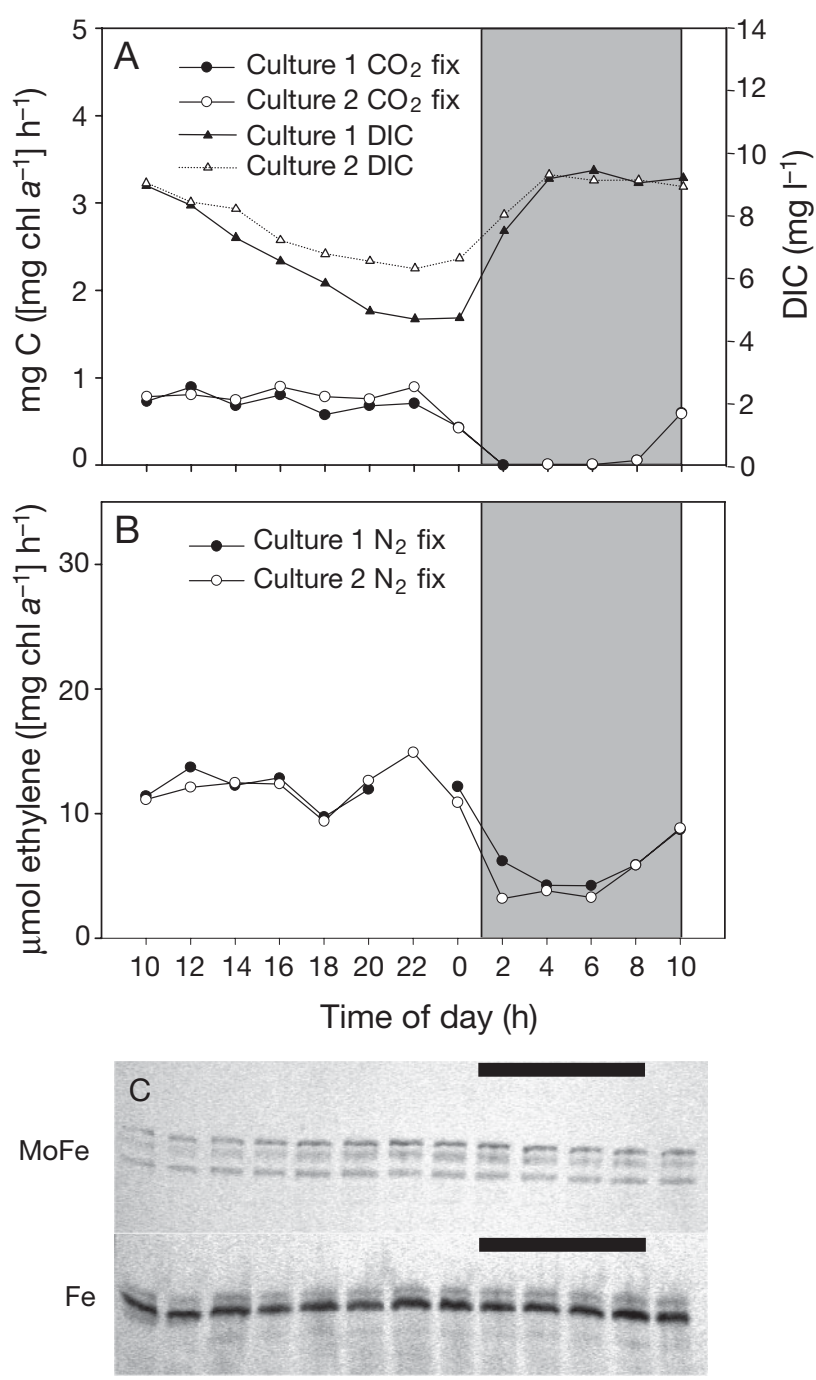

Fig. 7. Nodularia spumigena. (A) $\mathrm{CO}_{2}$ fixation $\left({ }^{14} \mathrm{C}\right.$ incorporation) and dissolved inorganic carbon concentration (DIC); (B) $\mathrm{N}_{2}$ fixation (acetylene reduction); and (C) immunoblotting of the 2 nitrogenase proteins $(\mathrm{Fe}$, dinitrogenase reductase; $\mathrm{MoFe}$, dinitrogenase) from the 15:9 h light:dark diel experiment. The $N$. spumigena strain was cultivated in duplicate cultures (Cultures 1 and 2). Darkened areas (A,B) and bars (C) indicate the time period when cultures were in darkness. Incubations that started at midnight were kept in light in the first hour, and in darkness in the second hour

evidenced by the high efficiency by which the antibody against the Azotobacter vinelandii ( $\gamma$-Proteobacterium) $\mathrm{Fe}$ protein binds the Fe protein from cyanobacteria. However, the observed differences in binding capacity and mobility of the MoFe protein between $N$. spumigena and 2 other heterocystous cyanobacteria (Anabaena aphanizomenoides and Anabaenopsis sp., data not shown) suggest that MoFe proteins in these cyanobacteria have important structural differences that require clarification. The data also revealed that the MoFe protein in N. spumi- gena was not structurally modified or subject to changes in abundance in response to darkness. Taken together, the data suggest that diel patterns of $\mathrm{N}_{2}$ fixation in $N$. spumigena and Aphanizomenon sp. are either under transcriptional or posttranslational control over the diel cycle, by a mechanism that does not significantly affect the integrity of either Fe or MoFe (in N. spumigena) proteins. The ability to keep fixing $\mathrm{N}_{2}$ at relatively high rates and maintain integrity of the nitrogenase proteins in the dark in Baltic Sea cyanobacteria may play a role in their ecological success in this environment. This ability allows these cyanobacteria to maximize their $\mathrm{N}_{2}$ fixation and growth during periodic $\mathrm{P}$ pulses to the euphotic layer.

Cyanobacterial blooms have been occurring in the Baltic Sea for thousands of years (Bianchi et al. 2000), but recently the blooms appear to have intensified. Long-term data sets suggest that phosphate concentrations are increasing in some surface and deep waters, while they are decreasing or remaining constant in others (Rahm \& Danielsson 2001). Yet there is a net input of approximately $32000 \mathrm{t} \mathrm{P} \mathrm{yr}^{-1}$ into the Baltic Sea (Wulff et al. 2001). The sediments and bottom waters in the Baltic Sea continue to serve as a rich source of $\mathrm{P}$ that, under conditions of bottom water anoxia enhanced by eutrophication, maintains the potential to support future cyanobacterial blooms.

Acknowledgements. Funding was provided by the Academy of Finland (BIREME program) to K.S. and National Science Foundation Grant 0452324 to H.W.P. and P.H.M. We thank R. Autio and M. Laamanen for space on board RV 'Aranda', and T. Steppe, P. Sanderson, C. Tallent, M. Leonard, S. Hyvärinen, K. Halinen, T. Roine, and the personnel of FIMR on board RV 'Aranda' for assistance. We also acknowledge the FIMR chemistry group for providing nutrient data, P. Ludden and $\mathrm{G}$. Roberts for donating the nitrogenase antibodies and proteins, and J. Zehr for providing laboratory space and comments on an early version of the manuscript.

\section{LITERATURE CITED}

Baltic Marine Environment Protection Commission (1983) Guidelines for the Baltic Sea monitoring programme for the second stage. Baltic Sea Environ Prot Comm 12

Baltic Marine Environment Protection Commission (1988) Guidelines for the Baltic Sea monitoring programme for the third stage: Part D. Biological determinants. Baltic Sea Environ Prot Comm 27D

Bianchi TS, Westman P, Rolff C (2000) Cyanobacterial blooms in the Baltic Sea: natural or human induced? Limnol Oceanogr 45:716-726

Durner J, Böhm I, Hiltz H, Böger P (1994) Posttranslational modification of nitrogenase: differences between the purple bacterium Rhodospirillum rubrum and the cyanobacterium Anabaena variabilis. Eur J Biochem 220: $125-130$

Evans AM, Gallon JR, Jones A, Staal M, Stal LJ, Villbrandt M, Walton TJ (2000) Nitrogen fixation by Baltic Sea 
cyanobacteria is adapted to the prevailing photon flux. New Phytol 1447:285-297

Gallon JR, Evans AM, Jones DA, Albertano P, Congestri R, Bergman B, Gundersen K, Orcutt KM (2002) Maximum rates of $\mathrm{N}_{2}$ fixation and primary production are out of phase in a developing cyanobacterial bloom in the Baltic Sea. Limnol Oceanogr 47:1514-1521

Hagström Å, Azam F, Kuparinen J, Zweifel UL (2001) Pelagic plankton growth and resource limitations in the Baltic Sea. In: Wulff FV, Rahm LA, Larsson P (eds) A systems analysis of the Baltic Sea. Springer Verlag, Berlin, p 177-210

Kahru M, Horstmann U, Rud O (1994) Satellite detection of increased cyanobacteria blooms in the Baltic Sea: natural fluctuation or ecosystem change? Ambio 23:469-472

Kahru M, Leppänen JM, Rud O, Savchuk OP (2000) Cyanobacteria blooms in the Gulf of Finland triggered by saltwater inflow into the Baltic Sea. Mar Ecol Prog Ser 207: 13-18

Kiirikki M, Inkala A, Kuosa $H$, Pitkänen $H$, Kuusisto $M$, Sarkkula J (2001) Evaluating the effects of nutrient load reductions on the biomass of toxic nitrogen-fixing cyanobacteria in the Gulf of Finland, Baltic Sea. Boreal Environ Res 6:131-146

Kononen K, Kuparinen J, Mäkelä K, Laanemets J, Pavelson J, Nõmmann S (1996) Initiation of cyanobacterial blooms in a frontal region at the entrance to the Gulf of Finland, Baltic Sea. Limnol Oceanogr 41:98-112

Kuparinen J, Tuominen L (2001) Eutrophication and selfpurification: counteractions forced by large-scale cycles and hydrodynamic processes. Ambio 30:190-194

Laemmli UK (1970) Cleavage of structural proteins during the assembly of the head of bacteriophage T4. Nature 227: $680-685$

Larsson U, Hajdu S, Walve J, Elmgren R (2001) Baltic Sea nitrogen fixation estimated from the summer increase in upper mixed layer total nitrogen. Limnol Oceanogr 46:811-820

Lehtimäki J, Moisander P, Sivonen K, Kononen K (1997) Growth, nitrogen fixation, and nodularin production by two Baltic Sea cyanobacteria. Appl Environ Microbiol 63: 1647-1656

Leppänen JM, Niemi $\AA$, Rinne I (1988) Nitrogen fixation of cyanobacteria (blue-green algae) and the nitrogen cycle of the Baltic Sea. Symbiosis 6:181-194

Ludden PW, Burris RH (1978) Purification and properties of nitrogenase from Rhodospirillum rubrum and evidence for phosphate, ribose, and an adenine-like unit covalently bound to the iron protein. Biochem J 175:251-259

Moisander PH, McClinton E III, Paerl HW (2002) Salinity effects on growth, photosynthetic parameters, and nitrogenase activity in estuarine planktonic cyanobacteria. Microb Ecol 43:432-442

Moisander PH, Steppe TF, Hall NS, Kuparinen J, Paerl HW (2003) Variability in nitrogen and phosphorus limitation for Baltic Sea phytoplankton during nitrogen-fixing cyanobacterial blooms. Mar Ecol Prog Ser 262:81-95

Nehring D (1981) Phosphorus in the Baltic Sea. Mar Pollut Bull 12:194-198

Niemi Å (1979) Blue-green algal blooms and N:P ratio in the Baltic Sea. Acta Bot Fenn 110:57-61

Editorial responsibility: Otto Kinne (Editor-in-Chief), Oldendorf/Luhe, Germany
Nordlund S (2000) Regulation of nitrogenase activity in phototrophic bacteria by reversible covalent modification. In: Triplett E (ed) Prokaryotic nitrogen fixation: a model system for analysis of a biological process. Horizon Scientific, Wymondham, p 149-164

Paerl HW (1990) Physiological ecology and regulation of $\mathrm{N}_{2}$ fixation in natural waters. Adv Microb Ecol 11:305-344

Pavelson J, Laanemets J, Kononen K, Nõmmann S (1997) Quasi-permanent density front at the entrance to the Gulf of Finland: response to wind forcing. Cont Shelf Res 17: 253-265

Rahm L, Danielsson $\AA$ (2001) Statistical analysis of spatial and temporal variations in the Baltic Sea. In: Wulff FV, Rahm LA, Larsson P (eds) A systems analysis of the Baltic Sea. Springer Verlag, Berlin, p 329-351

Rippka R (1988) Isolation and purification of cyanobacteria. Methods Enzymol 167:3-27

Rydin E, Hyenstrand P, Gunnerhed M, Blomqvst P (2002) Nutrient limitation of cyanobacterial blooms: an enclosure experiment from the coastal zone of the NW Baltic Proper. Mar Ecol Prog Ser 239:31-36

Stal LJ, Walsby AE (1998) Daily integral of nitrogen fixation by planktonic cyanobacteria in the Baltic Sea. New Phytol 139:665-671

Stal LJ, Staal M, Villbrandt M (1999) Nutrient control of cyanobacterial blooms in the Baltic Sea. Aquat Microb Ecol 18:165-173

Steemann Nielsen E (1952) The use of radio-active carbon $\left(\mathrm{C}^{14}\right)$ for measuring organic production in the sea. J Cons Int Explor Mer 18:117-140

Vahtera E, Laanemets J, Pavelson J, Huttunen M, Kononen K (2005) Effect of upwelling on the pelagic environment and bloom-forming cyanobacteria in the western Gulf of Finland, Baltic Sea. J Mar Syst 58:67-82

Vuorio H, Rinne I, Sundman V (1978) Nitrogen fixation of planktonic blue-green algae in the Helsinki sea area determined acetylene reduction. Aqua Fenn 8:47-56

Wallström K, Johanssen S, Larsson U (1992) Effects of nutrient enrichment on planktic blue-green algae in the Baltic Sea. Acta Phytogeogr Suec 78:25-31

Wasmund N, Voss M, Lochte K (2001) Evidence of nitrogen fixation by non-heterocystous cyanobacteria in the Baltic Sea and re-calculation of a budget of nitrogen fixation. Mar Ecol Prog Ser 214:1-14

Welschmeyer NA (1994) Fluorometric analysis of chlorophyll $a$ in the presence of chlorophyll $b$ and pheopigments. Limnol Oceanogr 39:1985-1992

Wulff F, Rahm L, Hallin AK, Sandberg J (2001) A nutrient budget model of the Baltic Sea. In: Wulff FV, Rahm LA, Larsson P (eds) A systems analysis of the Baltic Sea. Springer Verlag, Berlin, p 353-372

Yoch DC, Li J, Hu CZ, Scholin C (1988) Ammonia switch-off of nitrogenase from Rhodobacter sphaeroides and Methylosinus trichosporium: no evidence for Fe protein modification. Arch Microbiol 150:1-5

Zehr JP, Wyman M, Miller V, Duguay L, Capone DG (1993) Modification of the Fe protein of nitrogenase in natural populations of Trichodesmium thiebautii. Appl Environ Microbiol 59:669-676

Submitted: December 8, 2006; Accepted: March 12, 2007 Proofs received from author(s): August 27, 2007 